\title{
TEACHERS’ INFLUENCE ON STUDENTS IN THEIR LIFELONG DEVELOPMENT
}

\author{
Flavia Mălureanu \\ University of Bucharest \\ Luiza Enachi-Vasluianu \\ University of Bucharest
}

\begin{abstract}
The impact teachers have on their students is imprinted to a much extent in each person's life. Every child, teenager or adult speaks of present or previous experiences related to teachers who left their marks on their development in life. Teachers are important people in children's life providing them with education, discipline, motivation and role-models. The guiding role of teachers is not limited to school classroom and school disciplines, but it surpasses didactic activities and extends into personal life. Truth is that children feel differently the influence exerted by teachers due to their sensitivity, personalities, life experiences. The identification of the aspects that influence students to a greater or less extent is important as it helps to shape a profile of an authentic teacher as s/he is perceived by students. Such a perspective may help teachers become aware of their role in students' lives and as a consequence they should make adjustments in order to become better partners for their students.

The present paper intends to study teachers' impact on students in their life lifelong development. The aspects taken into consideration, according to specific literature and experiences in classrooms, were: school performances, behavioural patterns, adjustment to school requirements, motivation for learning, professional choices for future careers, outlooks on life. The research methods were the investigation based on questionnaire, the conversation and the systematic observation. The participants in the research were 200 students from two school levels: high school (students 15-19 years old) and faculty (students 19-30 years old). The data collected were processed using the SPSS analysis. The results of the research could be used to increase teachers' awareness on their impact on students in their lifelong development.
\end{abstract}

Keywords: Lifelong development, Student's perception of the teacher, Teachers' influence on students.

\section{Introduction}

Generally speaking, lifelong development refers to one’s development with the purpose of achieving personal fulfilment. As part of society, people need to develop and grow through learning, experiencing, socialization etc. Personal fulfilment and development throughout life refers to personal, emotional, 
professional, social growth. In short, lifelong development means improving one's own quality of life and sense of self-worth (Duclos, 2018).

Lifelong development begins inside a formal education institution. That is why, teacher-student relationship is important and may have a major influence on student development. The student does not only acquire knowledge and skills from their teachers, but also values, interaction skills, perspectives on the world. As such teachers' influence on students surpasses the didactic span and prolongs into their personal and social life. For this reason, teachers have to carefully exert their attributes on the individuals forming the classroom group and on the group as a whole. They must make decisions, organize, guide, council, appreciate, they must be models of positive moral and civic behaviour. The goal is to form prosocial behaviours, to direct interpersonal relationships within the group in order to ensure a positive psychosocial climate needed for the harmonious development of students' personalities.

The influence teachers have on their students is obvious if we take into considerations the emotions teachers stir in children. On the one hand, students may foster much admiration, respect and even affection for their teacher; on the other hand, students may harbour negative feelings for their teacher. The teacher influences the student directly through their active presence transposed into attitude, verbal message, gestures, mimics, affective state and personal example. Indirectly, the teacher influences their students through other educational factors such as family, teaching council, parents' committee, students' collective etc. Teachers' influence is determining on aspects such as: students' self-esteem, students' motivation for learning, students' school performances, students' behavioural patterns, students' adjustment to school requirements, students' professional choice for future careers, outlook on life.

\section{Literature Review}

For a harmonious development each child has to develop a positive feeling of one's identity as this is the inner mirror through which each individual sees and identifies oneself (Vrăsmaș, 2014). Teachers play an important role in shaping student's self-esteem. More accurately, they can encourage students and help them create powerful self-esteem, or, on the contrary, they can often criticise them, thus affecting their self-esteem. A student with low self-esteem comes across real problems in his school activity, as well as in the future since a person with low self-esteem does not have a satisfactory life. On the other hand, a supportive teacher who encourages and avoids personalised criticism, who creates trustworthy and cooperative atmosphere can sustain the formation of high self-esteem (Mălureanu \& Enachi-Vasluianu, 2019). A child with high selfesteem manifests among other characteristics certitude, trust in one's skills, the 
ability to perceive and accept the differences from the others, motivation for learning, perseverance in front of difficulties (Duclos, 2018).

Teachers can engage student's interest for learning, or, on the contrary, they can make it seem difficult and dull. It all depends on the way the teacher interacts with the students and the way they display the information. Teachers who can explain the information so that the student can easily understand it, who do not assess relying on memorisation only can stimulate the child to manifest interest in learning. If the teacher-student relationship is positive, than the motivation, be it intrinsic or extrinsic, is enhanced. The targeted goals are considered as having personal value, competence motivation and autonomous motivation. At the same time, teacher's positive attitude and enthusiasm with teaching and learning has students develop positive affect and enthusiasm for learning and academic achievement (Wood, 2017). As such, students' school aspirations and performances are mainly influenced by the teacher, the way s/he knows to support them, to appreciate their results and constructively assess them (Davis, 2013), without affecting their self-esteem.

Teachers influence students' school performances through their teaching and assessing. Some research showed that teachers' expectations of their students also directly influence their academic performances (Neculau \& Boncu, 1999). That is, if the teacher has positive expectations from a student $s / h e$ perceives as intelligent and diligent s/he will pay special attention to that student by giving him more explanations, encouraging him, overlooking his mistakes etc. As a consequence, the student feels encouraged to raise to teacher's expectations and puts a lot more effort in his work. By contrast, when the teacher has negative expectations from a student labelled as troublesome, that student will not be stimulated to have good school results, he will feel blocked by criticism and lack of self-confidence.

Teachers are models of behavioural patterns for students. Irrespective of their will, teachers act as models in front of their students influencing their thinking and their behaviour (Pânişoară, 2009). Most of the times, students assume teacher's behavioural elements. They can adopt teacher's facial expressions, gestures and way of communication. As teacher's behavioural patterns are copied to a great extent, then s/he should display permanent selfcontrol, self-imposed equilibrium. The emotional behaviour of teachers influences students' behaviour directly through contamination and indirectly through the affective climate imposed in the classroom. This behaviour can stimulate invigorating affective states or can diminish students' work capacity and block the communication flow between the teacher and the student.

Positive psychosocial development is important for students as it can lead to good outcomes such as academic achievement, good social functioning, wellbeing, reduced dropouts rates, boredom and disengagement with learning 
activities (Wood, 2017). The teacher influences student's adjustment to school environment. By developing and maintaining a good relationship with the student, this one copes with school rules and tasks, is motivated to take active part in the school activities, to develop good relationships with their peers and other teachers, feels integrated in the school environment. As a rule, teacher's availability for cooperation influences voluntary involvement of the student in his own formation. The student who has a good relationship with the teacher is motivated to learn, to accept advice and criticism more easily. By contrast, negative teacher-student relationship deprives the student of satisfaction and motivation and makes him lose respect for school environment.

Teachers can influence student's professional aspirations. Many times, teachers grasp a special potential of the student and guide him/her in accordance to a certain professional path, inspiring them with their own passion for study, for performance. Some teachers who are loved and admired can become professional models for later. Many adults admit that they chose their careers according to their favourite teacher's specialization. Some became teachers themselves following the model of the teacher admired.

Teachers' influence on students does not limit to education and school performances. There are times when children would rather solicit teacher's help or advice especially with problems at home or issues related to their peers (since teachers are more familiar with school environment). Additionally, at all times, teachers constitute a source of influence that can modify certain percepts or trigger others. Ideally, students should copy from the teachers they interact with an optimist perspective on life, a courageous approach to challenges, perseverance in touching goals. Irrespective of the negative or positive influence, the role of the teacher is prominent and its correct exercise depends on his/her personality, the educational situations they come across with and deal with.

\section{Methodology of Research}

Objectives - The research objectives are a) to identify the aspects that influence students' lifelong development in their relationship with teachers, b) to realize descriptive analyses of the selected elements in order to determine a hierarchy for the students from high school and faculty.

Participants - The sample used for research was made of 100 students from high schools, from urban and rural areas (aged 16 to 19), and 100 students from one faculty with pedagogical majoring (aged 19 to 35) from Vrancea County, Romania. The participation in the research was done based on volunteering. The sample needed to be old enough to have gone through various experiences of 
life and to be able to treat as objectively as possible matters of teachers' influence in their personal development.

Research instrument - The research was accomplished based on a questionnaire addressed to the sample described above. The questionnaire was made of seven items: shaping self-esteem, school performances, behavioural patterns, adjustment to school requirements, motivation for learning, professional choices for future careers and outlooks on life. The answers were variants of a five-step scale: (1) to a very low extent, (2) to a low extent, (3) to an average extent, (4) to a large extent, (5) to a very large extent. Students' choices showed each item's relevance for the teacher's influence on their lifelong development. Mention must be made that our research took into account teacher's positive influences on the students. The teacher under the lens is the supportive teacher who is responsive to students' needs and promotes good social outcomes.

\section{Results and Discussion}

The SPSS software was used for the descriptive analyses, the t-test for the independent samples.

\section{Table 1 Means and Standard Deviation of Indicators of Teachers' Influence on Students in Their Lifelong Development}

\begin{tabular}{|c|c|c|}
\hline $\begin{array}{c}\text { Items o of teachers' influence } \\
\text { on students in their lifelong } \\
\text { development }\end{array}$ & $\begin{array}{c}\text { High school Mean } \\
\text { (std. dev.) }\end{array}$ & $\begin{array}{c}\text { Faculty Mean } \\
\text { (std. dev.) }\end{array}$ \\
\hline Shaping self-esteem & $4.84(0.438)$ & $4.78(0.418)$ \\
\hline Outlooks on life & $4.56(0.614)$ & $4.20(0.670)$ \\
\hline $\begin{array}{c}\text { Adjustment to school } \\
\text { requirements }\end{array}$ & $4.46(0.563)$ & $4.10(0.931)$ \\
\hline Behavioural patterns & $4.36(0.874)$ & $4.42(0.612)$ \\
\hline $\begin{array}{c}\text { Professional choices for future } \\
\text { careers }\end{array}$ & $4.24(0.960)$ & $4.16(0.940)$ \\
\hline Motivation for learning & $4.18(0.661)$ & $4.74(0.702)$ \\
\hline School performance & $4.02(1.185)$ & $4.76(0.262)$ \\
\hline
\end{tabular}

Source: Authors

Using the means in Table 1 we established a hierarchy of the indicators for the teacher's influences on students in their lifelong development for high school and faculty levels. As such, the indicator ranking 1st was viewed as most influential on students, whereas the item in the 7th rank was perceived as less important for the same purpose. 
Table 2 Descriptive of Hierarchy of Indicators of Teachers' Influence on Students in Their Lifelong Development

\begin{tabular}{|c|c|c|}
\hline Rank & High school & Faculty \\
\hline 1. & Shaping self-esteem & Shaping self-esteem \\
\hline 2. & $\begin{array}{c}\text { Outlooks on life } \\
\text { Adjustment to school } \\
\text { requirements }\end{array}$ & Motivation for learning \\
\hline 3. & Behavioural patterns & Behavioural patterns \\
\hline 4. & $\begin{array}{c}\text { Professional choices for } \\
\text { future careers }\end{array}$ & Outlooks on life \\
\hline 5. & Motivation for learning & $\begin{array}{c}\text { Professional choices for } \\
\text { future careers }\end{array}$ \\
\hline 6. & School performance & $\begin{array}{c}\text { Adjustment to school } \\
\text { requirements }\end{array}$ \\
\hline 7. & & \\
\hline
\end{tabular}

Source: Authors

As Table 1 shows, the highest mean in high school as well as in college was recorded for self-esteem, with the value of $\mathrm{m}=4.84$ in high school and $\mathrm{m}=4.78$ in faculty. The answers of the two samples clearly showed that the teacher's influence on students' self-esteem is very important. Irrespective of the age, being encouraged, having positive feedback on learning or behavioural efforts helps students develop self-confidence. This influences students' formation of positive self-esteem. The items ranking second and third for high school are outlooks on life $(\mathrm{m}=4.56)$ and adjustment to school requirements $(\mathrm{m}=4.46)$. High school students are easily influenced. An optimist outlook on life can help them believe in their future and in what it has in store for them if they get actively involved. In regard to adjustment to school environment, students need to feel accepted and valued within the group, that is why a teacher-student relationship based on mutual trust and collaboration will help the student to adjust more easily to school requirements and be more open with the others. The second and the third ranks for faculty are for school performance $(\mathrm{m}=4.76)$ and motivation for learning $(\mathrm{m}=4.74)$.

The lowest mean in high school is for school performances $(\mathrm{m}=4.02)$, whereas for faculty the lowest mean is for adjustment to school requirements $(\mathrm{m}=4.10)$. With the other items, the hierarchic order varies as shown in Table 2.

The two items ranking last in high school hierarchy are motivation for learning and school performances which are viewed in a dependent relationship. They show that teacher's influence on both motivations for learning $(\mathrm{m}=4.18)$ and school performances $(\mathrm{m}=4.02)$ decrease in importance for students. This is possible because in high school there is a decrease in motivation for learning during the first years, a lower involvement of students in school activities due to the fact that, in general, the results of learning are not considered so important by students. School results during high school years are of little importance for the 
enrolment in faculty or future career. Students consider the results of the last year of high school to be important when preparing for the final exams. Their baccalaureate (final high school exam) mean is important for college admission, being a condition of admission or even percentage of the mean for admission. By contrast, school performances and motivation for learning ranked second and third in the faculty hierarchy with $\mathrm{m}=4.76$ for the former and $\mathrm{m}=4.74$ for the latter. This is due to the fact that the grades obtained during faculty are important for scholarship grants and the annual ranking which allow students to preserve or lose their tax free enrolment.

The lowest mean registered for faculty is for adjustment to school requirements $(\mathrm{m}=4.10)$. This is motivated by students being more independent, as the model offered by influential teachers is no longer so important in relation to their own value judgments. With the other items, the hierarchic order varies as shown in Table 2.

We applied the $\mathrm{T}$ test for the independent groups in order to determine the differences between opinions of the students from high school and faculty regarding the teachers influence on students' lifelong development. The significance level was set to 0.05 . Starting from the significant differences from a statistical point of view among the appreciations of the students we can state the relevance of the items which determine the degree of influence for each school level.

Analysing the appreciations of the students we notice significant differences for four items (outlooks on life, adjustment to school requirements, motivation for learning and school performance, $\mathrm{p}<0.05$ ). For the first two items the means are higher for high-school than for faculty, which shows that the students in high school appreciate outlooks on life and adjustment to school environment as having greater relevance for students' lifelong development. For the other two items the means are higher for faculty than for high school as motivation for learning and school performances were considered of greater relevance for the former school level.

The data analysis shows that there are statistically insignificant differences between three items: shaping self-esteem, professional choice for the future, behavioural patterns. This demonstrates convergence of appreciations between the investigated groups.

\section{Conclusions}

The paper focussed on the study of teacher's influence on students in their lifelong development. Teacher's influence on students is important as it affects students not only during school span, irrespective of the level, but also during 
their lifelong development. As such, these influences can develop into a positive model of action in students' personal, social and professional life.

Good knowledge of the impact of their own actions, of the interaction with the students will allow teachers to better conform to students' expectations, which will increase the chances of success of teacher-student interaction. In order for the teacher to construct efficient didactic activities and profound relationships with the students, s/he needs to know the way s/he may influence their students positively.

Of equal importance with teacher's influence on students is his/her being influenced by the students. An efficient didactic process means constant adjustment of teacher's actions to student's personality and to the characteristics of the group s/he interacts with. As such, the teacher adjusts his/her behaviour, consults with his students, thus getting feedback regarding his/her influence exerted on the students. This research could be continued with the study of the aspects which influence teachers and what they take from their relationships with their students. On the other hand, we consider that one of the limitations of the study is the variety of participants. If we had included alumni in the sample of research, maybe the data of the study would have been more varied and more objective as the alumni had grown detached from the school institutions.

\section{References}

Davis, H. (2013). Teacher-Student Relationships. In J. Hattie \& E.M. Anderman (Eds.), International Guide to Student Achievement. London: Routledge.

Duclos, G. (2018). L'estime de soi, un passeport pour la vie. Montreal: Editions du CHU Sainte Justine.

Mălureanu, F. \& Enachi-Vasluianu, L. (2019). Strategies of Promoting Well-Being in School Activities in the Romanian Educational System. Proceedings of the 13th International Scientific Conference "Society. Integration. Education", Vol. II, Rezekne Academy of Technologies, 311-319.

Neculau, A. \& Boncu, Ș. (1999). Dimensiuni psihosociale ale activității profesorului. In A. Cosmovici and L. Iacob (Eds), Psihologie școlară. Iași: Polirom.

Pânișoară, I. O. (2009). Profesorul de succes: 59 de principii de pedagogie practică. Iași: Polirom.

Vrăsmaș, E. (2014). Educația timpurie. București: Arlequin.

Wood, R. (2017). The Influence of Teacher-Student Relationships and Feedback on Students' Engagement with Learning. Cambridge: Cambridge Scholar Publishing. 